DOI: https://doi.org/10.24127/ajpm.v9i4.3165

\title{
VISUAL THINKING STRATEGIES BASED PICTURE BOOK MEDIA FOR THEMATIC LEARNING IN ELEMENTARY SCHOOLS
}

\author{
Sutama $^{1^{*}}$, Nur Asih Wulandari ${ }^{2}$, Naufal Ishartono ${ }^{3}$, Sabar Narimo $^{4}$, Anam Sutopo ${ }^{5}$ \\ $1^{*}, 2,3,4,5$ Universitas Muhammadiyah Surakarta, Surakarta, Indonesia \\ *Corresponding author. Sutama. Jl. Ahmad Yani, Pabelan, Kartasura, 57162, Surakarta, Jawa Tengah, Indonesia \\ E-mail: $\quad$ sutama@ums.ac.id ${ }^{1 *}$ \\ q200170021@student.ums.ac.id ${ }^{2)}$ \\ ni160@ums.ac.id ${ }^{3)}$ \\ sabar.Narimo@ums.ac.id ${ }^{4)}$ \\ anam.Sutopo@ums.ac.id ${ }^{5)}$
}

Received 16 October 2020; Received in revised form 27 December 2020; Accepted 31 December 2020

\begin{abstract}
The research in this article aims to develop a picture book based on visual thinking strategies for thematic learning in elementary schools. This is specifically intended to test the feasibility of the media developed in aspects of 1) material, 2) media, 3) teacher response, and 4) student response. This research is categorized as research and development. Research subjects for limited trials were teachers and third-grade students of SD Muhammadiyah 16 Karangasem consisting of 2 teachers and 9 students. The type of research is qualitative evaluative. The data were obtained from the validation assessment of material experts, media experts, teachers, and students' responses. The data analysis technique was conducted through flow and constant comparison methods. Based on the results, the assessments of the media developed are 1) material experts earned a score of 62 with suitable category, 2) media experts obtained a score of 45 with suitable category, 3) teacher responses scored 44 with very suitable category, and 4) student responses gained a score of 14.1 with very suitable category. To conclude, the picture book based on visual thinking strategies is suitable for learning media in elementary schools.
\end{abstract}

Keywords: introductory schools; learning media; learning strategies; picture books; thematic learning; visual thinking strategies

\begin{abstract}
Abstrak
Penelitian dalam artikel ini bertujuan untuk mengembangkan buku bergambar berbasis strategi berpikir visual untuk pembelajaran tematik di sekolah dasar. Hal ini secara khusus dimaksudkan untuk menguji kelayakan media yang dikembangkan pada aspek 1) materi, 2) media, 3) respon guru, dan 4) respon siswa. Penelitian ini dikategorikan sebagai penelitian dan pengembangan. Subjek penelitian pada penelitian terbatas ini adalah guru-guru dan siswa kelas tiga di SD Muhammadiyah 16 Karangasem yang terdiri dari 2 guru dan 9 siswa. Data diperoleh dari penilaian validasi ahli materi, ahli media, guru, dan tanggapan siswa. Teknik analisis data dilakukan dengan metode perbandingan aliran dan konstan. Berdasarkan hasil penilaian terhadap media yang dikembangkan adalah 1) ahli materi memperoleh skor 62 dengan kategori sesuai, 2) ahli media memperoleh skor 45 dengan kategori sesuai, 3) tanggapan guru memperoleh skor 44 dengan kategori sangat sesuai, dan 4) Respon siswa memperoleh skor 14,1 dengan kategori sangat sesuai. Kesimpulannya, buku bergambar berbasis strategi berpikir visual cocok untuk media pembelajaran di sekolah awal.
\end{abstract}

Kata kunci: buku bergambar; media pembelajaran; pembelajaran tematik; strategi pembelajaran; sekolah pendahuluan; strategi berpikir visual 


\section{INTRODUCTION}

Visual Thinking Strategies (VTS) is a learning strategy that improves students' critical thinking skills through teacher-student discussions via visual images. Yenawine (2013), in his book entitled Visual Thinking Strategies, states that VTS uses art to teach visual literacy, thinking, and communication skills such as listening and expressing oneself. The role of visual images in the learning process is to provide a learning experience for students to dig deeper and critically related to the context and concept behind the images presented. The uniqueness of this strategy attracts many researchers to test the benefits of applying VTS in learning processes such as increasing creativity and critical thinking (Moeller, Cutler, Fiedler, \& Weier, 2013), problem-solving skill (Ferrara, De Santis, \& Staffoli, 2015), and observational skill (Poirier, Newman, \& Ronald, 2020). From the study results, it can be said that VTS provides many benefits in improving students' skills.

Yenawine (2013), in his book, also states that the beginning of the application of VTS is in elementary school students where in this context, the thinking ability of elementary school students is still in the concrete phase or other words, their learning object is on objects that can be reached by the senses, one of which is the visual senses. Therefore, it is very relevant if VTS is applied to elementary school students. To meet the needs of visualization of the topics taught, a learning media can accommodate the implementation of VTS-based learning, one of which is through a picture book. In principle, the picture book is a medium in the form of a book that provides visualization of the message or concept that wants to be conveyed. In the context of learning media, Van den Heuvel-Panhuizen, Van de Boogaard, \& Doig (2009) stated that picture books support the process of improving students' understanding and skills, which in the context of their research is mathematical thinking. Therefore, the integration between VTS and picture book is considered very relevant to be developed.

In Indonesia, the elementary school level's learning curriculum is the 2013 curriculum, one of the characteristics of the thematic learning concept. Riadi (2020) define it as a form of integrated learning model that combines a concept in several materials, lessons, or fields of study into one particular theme or topic of discussion so that there is an integration between knowledge, skills, and values that allow students to actively discover scientific concepts and principles holistically, meaningfully and authentically. From this definition, in thematic learning, teachers must link a material between subjects into an exciting learning path. If reviewed further and associated with the characteristics of the picture book, then the essence of thematic learning is related to how to present the material by related to the inter-topic in line with the characteristics of the picture book that must also be able to relate between materials to create a good storyline. Therefore, picture books based on Visual Thinking Strategies as a thematic learning media at the elementary school level become very relevant to be developed.

From previous research, there have been many research results that seek to improve the quality of thematic learning at the elementary school level where some of them such as the use of macro flash media, example-non-example method, mobile learning device, and using problem-based learning (Akbar et 
al., 2020; Jayanti, 2020; Rumanti, 2020; Septyanti, Kurniaman, \& Charlina, 2020). However, there are still very few research results that use picture books based on Visual Thinking Learning to improve thematic learning quality at the elementary school level. Therefore, the research questions that arise are on how to develop picture books based on Visual Thinking Learning to improve the quality of thematic learning at the elementary school level, and how the feasibility of visual thinking learningbased picture books to improve the quality of thematic learning at the elementary school level developed. So, the purpose of this research is to describe the process of developing picture books based on Visual Thinking Learning to improve the quality of thematic learning at the elementary school level, as well as describe the feasibility of picture books based on Visual Thinking Learning to improve the quality of thematic learning at the elementary school level developed.

\section{METHOD}

This research was categorized as research and development. Design development was carried out with a modification of the Borg \& Gall model (Ishartono, Juniati, Lukito, \& Surabaya, 2016; Sutama, 2019). Stages of development were 1) needs analysis (library studies, field surveys, and product drafting), 2) development (limited trials and broader trials), and 3) empirical product testing. Research subjects for limited trials were teachers and third-grade students of SD Muhammadiyah 16 Karangasem consisting of 2 teachers and 9 students. The broader trial subjects were teachers and third-grade students of SD Muhammadiyah 16 Karangasem including 2 teachers and 15 students. The subject material experts and media experts were two from academics/ lecturers and two from practitioners/ teachers, respectively.

Data were obtained from the validation assessment of material experts, media experts, teachers, and student responses. The material validation assessments consisted of 20 items (maximum score 100 and minimum score 20), relating to 1) 5 items for material coverage, 2) 5 items for material accuracy, 3) 4 items for material expertise, 4) 4 items for efforts to improve student understanding, and 5) 2 items for material development, as well as comments, suggestions, and improvement notes. The media validation assessments consisted of 14 items (maximum score 70 and minimum score 14), concerning 1) 5 items for cover, 2) 5 items for content, and 3) 4 items for picture, and the comments, suggestions, and improvement notes. The teacher responses contained 10 items (maximum score 50 and minimum score 10), regarding 1) 4 items for the suitability of the material, 2) 3 items for material coverage, and 3) 3 items for media use, as well as the comments, suggestions, and improvement notes. Students' responses contained 15 items, with 'yes' and 'no' answer choices (maximum score 15 and minimum score 0 ), as well as student suggestions and parent comments.

Data analysis was conducted by flow and constant comparison methods. The steps of data analysis of the feasibility of a picture book based on visual thinking strategies on Theme 7 Sub-theme 3 Learning 5 for third grade in SD Muhammadiyah 16 Karangasem, namely: 1) Shifting the assessment from qualitative to quantitative with a score of 5 for 'very good' criteria, 4 for 'good' criteria, 3 for 'fair' criteria, 2 for 'poor' criteria, and 1 for 'very poor' criteria; 2 ) 
DOI: https://doi.org/10.24127/ajpm.v9i4.3165

After the data were collected, then the average score was calculated; and 3) Converting the average score to a qualitative value based on category 1 ) very suitable (A), 2) suitable (B), 3) fair $(\mathrm{C}), 4)$ unsuitable (D), and 5) very unsuitable (E). Each conversion of the average score of material experts, media experts, teacher responses, and student responses is presented in Table 1 and Table 2.

Table 1. Conversion of Average Scores for Material and Media Expert Assessments

\begin{tabular}{|c|c|c|c|c|c|c|}
\hline \multicolumn{3}{|c|}{ Material Expert Assessments } & \multirow[t]{2}{*}{ Category } & \multicolumn{3}{|c|}{ Media Expert Assessments } \\
\hline No & Average Score & Score & & Score & Average Score & No \\
\hline 1. & $X>81,8$ & A & Very suitable & A & $X>57,8$ & 1. \\
\hline 2. & $60,6<X \leq 81,8$ & B & Suitable & B & $42,6<X \leq 57,8$ & 2. \\
\hline 3. & $39,4<X \leq 60,6$ & $\mathrm{C}$ & Enough suitable & $\mathrm{C}$ & $27,4<X \leq 42,6$ & 3. \\
\hline 4. & $18,2<X \leq 39,4$ & $\mathrm{D}$ & Not suitable & $\mathrm{D}$ & $12,2<X \leq 27,4$ & 4. \\
\hline 5. & $X \leq 18,2$ & $\mathrm{E}$ & Very inadequate & $\mathrm{E}$ & $X \leq 12,2$ & 5 . \\
\hline
\end{tabular}

Table 2. Conversion of Average Scores for Teacher and Student Responses

\begin{tabular}{|c|c|c|c|c|c|c|}
\hline \multicolumn{3}{|c|}{ Teachers Response } & \multirow[t]{2}{*}{ Category } & \multicolumn{3}{|c|}{ Students Response } \\
\hline No & Average Score & Score & & Score & Average Score & No \\
\hline 1 & $X>41,8$ & $\mathrm{~A}$ & Very suitable & $\mathrm{A}$ & $X>13,8$ & 1 \\
\hline 2 & $30,6<X \leq 41,8$ & $\mathrm{~B}$ & Suitable & B & $4,6<X \leq 13,8$ & 2 \\
\hline 3 & $19,4<X \leq 30,6$ & $\mathrm{C}$ & Enough suitable & $\mathrm{C}$ & $5,4<X \leq 4,6$ & 3 \\
\hline 4 & $8,2<X \leq 19,4$ & $\mathrm{D}$ & Not suitable & $\mathrm{D}$ & $1,2<X \leq 5,4$ & 4 \\
\hline 5 & $X \leq 8,2$ & $\mathrm{E}$ & Very inadequate & E & $X \leq 1,2$ & 5 \\
\hline
\end{tabular}

Research on the development of a picture book based on visual thinking strategies is determined by the proper criteria if the assessment results of each aspect are obtained at a minimum of good/suitable. The research procedure in this article is illustrated in Figure 1.

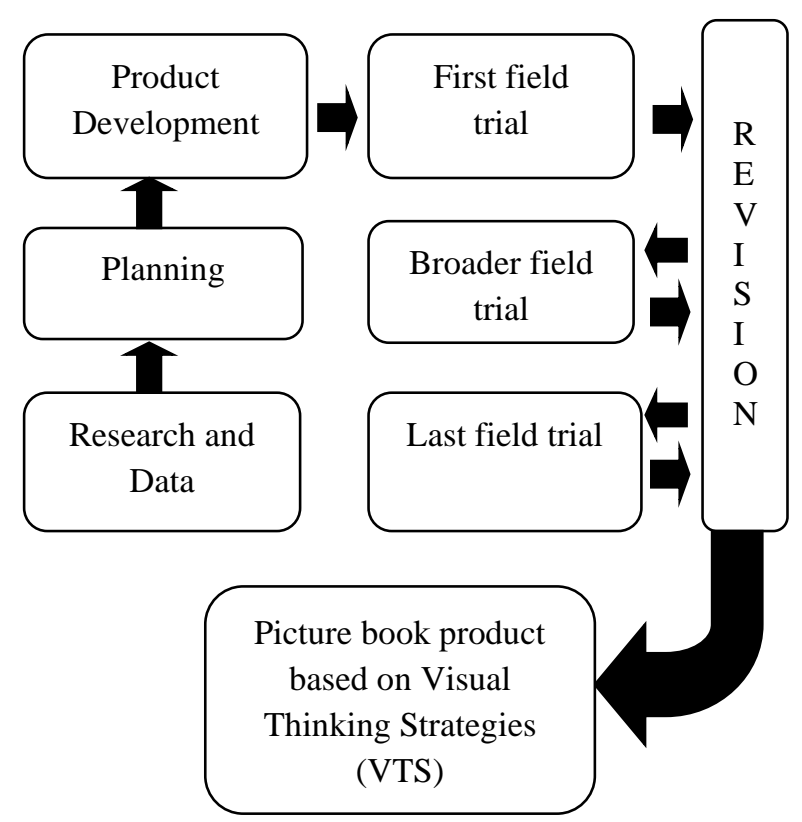

Figure 1. The determined research procedure. 


\section{RESULT AND DISCUSSION}

The book media is picture books based on visual thinking strategies, which contains learning material Theme 7 Sub Theme 3 Learning 5 for thirdgrade Elementary School. The design of media development was carried out with needs analysis, development, implementation, and evaluation in three stages, based on modifications from Rabiman, Nurtanto, \& Kholifah (2020). This development design shows good results in the implementation of offline and online learning in elementary schools. These results are supported by the fact that the book media based on visual thinking strategies based on Hailey, Miller, \& Yenawine, (2015) stages of learning visual thinking strategies are capable of directing one to build their knowledge, attitudes, and skills. This implies that the picture book media is in accordance with expectations in the thematic learning process.

Picture book based on visual thinking strategies consists of three components, namely cover, content, and evaluation sheets. The cover section contains the description of the theme, sub-themes, and learning as well as the title of the discussion material. The contents section contains teaching material that is presented through dialogue with the flow of visual thinking strategies. The evaluation sheet section contains practices as a benchmark for students' understanding of the material presented in the picture book. Picture book based on visual thinking strategies was built in three books for each theme. The purpose is the learning process can be conducted through the stages of visual thinking strategies discussion. The learning process with discussion is expected to improve knowledge and develop students' attitudes and skills. The picture books were made from A4 paper, $16 \mathrm{pt}$ font size, and comic sans font style. The purpose is to ease students to understand and attract third-grade students of elementary schools, also in line with the rules of writing a book. The illustration of the book can be seen in Figure 2.

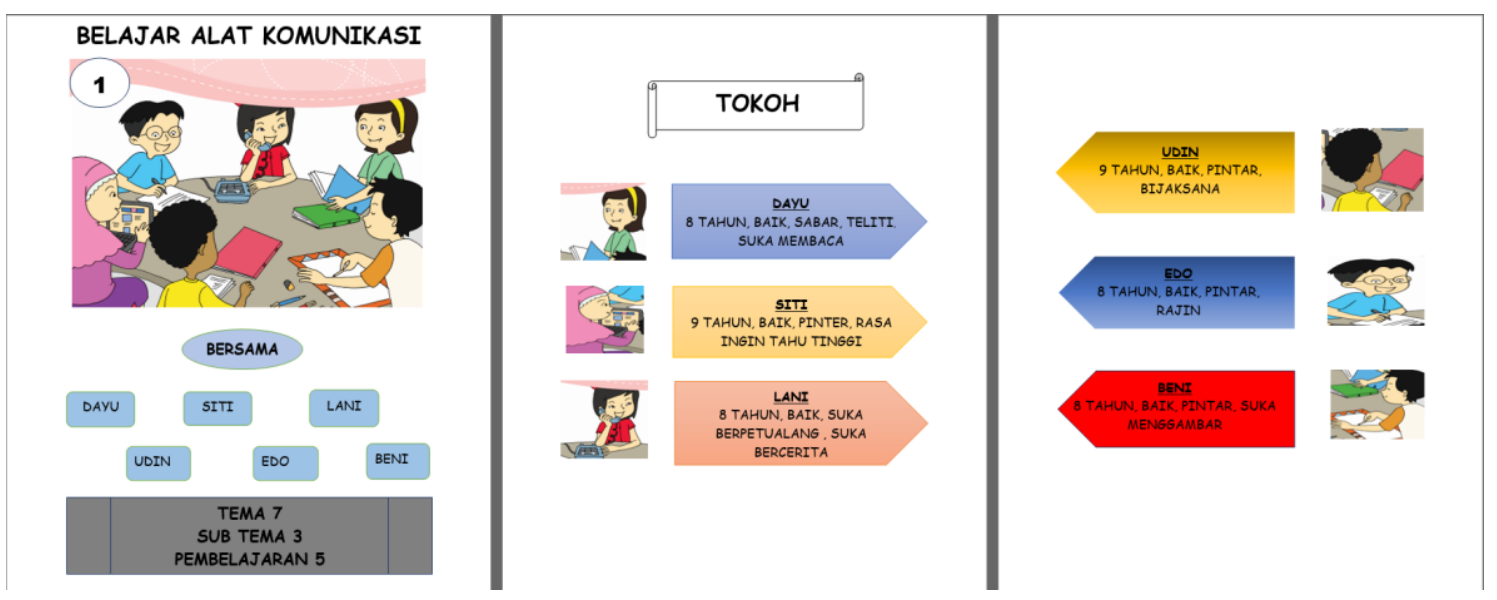

Figure 2. The illustration of some parts of the book.

The overall material validation assessment scored 62 or suitable category. The average score in each aspect, namely 1) material coverage score is 16 (from 5 items), 2) the accuracy of the material score is 15 (from 5 items), 3) the average material skill score is 13 (from 4 items), 4) efforts to increase students' understanding score is 12 (from 4 items), and 5) the 
development of the material score is 6 (from 2 items). In the section of comments, suggestions, and general improvement notes for books 1, 2, and 3 are already practical but there is a need for reflection from the material discussed at the end of each lesson. The picture book is feasible and practical, in line with the results of research stating that the practicality of teaching materials for teaching, reading, and understanding material, especially during the pandemic, greatly helps to improve the quality of thematic learning (Mella Hanifah, Mudjiran, \& Taufina., 2019).

As the aforementioned statement, the picture books contain fun and effective materials for offline and online learning although it only utilizes WhatsApp. This is following the statement that e-learning with the "WhatsApp" application which serves only as a communication tool between teachers and students and picture books as learning media will increase students' interest and learning outcomes (Zhanda, Molokwane, \& Motshegwa, 2020). The media developed encourages teachers and students to master teaching material more quickly. This is in accordance with the statement that the use of media is an alternative that can be done to accelerate the understanding of teachers and students. They further stated that the application of learning can be carried out online by maximizing the potential of existing technology using a combination of e-learning with picture books (Dhull \& Beniwal, 2019).

The overall media validation assessment scored 45 or 'suitable' category. The average score in each aspect, namely; 1) the cover score is 17 (from 5 items), 2) the contents score is 16 (from 5 items), and 3) the image score is 12 (from 4 items). The section of comments, suggestions, and improvement notes for books 1, 2, and 3 show the pictures and materials are harmonious and interesting, but impaired images are required to be fixed. The picture book based on visual thinking strategies has included thematic materials contained in the teacher's book or student's book, which can explain more detail and structured for students. Through the presentation based on visual thinking strategies, it can assist students' understanding of teaching material and students can follow the attitudes and skills presented through the characters in the picture books (Landorf, 2006). Learning with picture books based on visual thinking strategies keeps students engaged in critical thinking and stimulate good synergy between creativity and critical thinking to enable optimal learning.

Optimization of online learning can be performed by utilizing the picture books based on visual thinking strategies. This picture books create fun and exciting learning because it is presented like a comic, so it can increase student interest in learning and does not remove the thematic learning (Pritandhari, 2002). The picture book includes three components, namely knowledge, attitudes, and skills, thus, it is expected to improve student learning outcomes (Buchory, Selly R, 2017; Latifah \& Isnalini, 2015; Nugrahani \& Rupa, 2007).

Overall teacher response scored 44 or 'very suitable' category. The average score in each aspect, namely; 1 ) material suitability score is 20 (from 4 items), 2) the material coverage is 12 (from 3 items), and 3) the media usage score is 12 (from 3 items). Comments, suggestions, and improvement notes show the teacher's tendency to state children were fond of learning presented in picture books (comics) that contain 
pictures of figures and content of teaching materials. The interesting fact is students' reading interest increased. Furthermore, the teachers provided advice but it would be better if the contents are deepened and expanded so the picture books can fulfill students' needs and they can immediately understand and master the Basic Competencies that will be achieved through learning objectives. Eventually, the developed media is very feasible to involve students playing an active role in thematic learning. This is in accordance with the results of research Kusminah (2012) and Faizah (2009) stating that images are good for involving students in the learning process.

Thematic learning emphasizes more on student involvement in the learning process so that students can gain direct experience and are trained to discover the variety of knowledge for themselves to learn. Through direct experience with media assistance, students will understand the concepts and relate those to other concepts they understand. Thematic learning with picture books can serve as an alternative in online learning culture carried out following the development of thirdgrade elementary school students. The development of this habituation is influenced by the background of students and the school policies (Fatimah, Sutama, \& Aly, 2020). This habituation needs to be applied so education continues as it should, thus, good collaboration appears in the thematic learning process.

Thematic learning orients towards the application of the learning concept while doing other activities. Therefore, teachers are required to design learning experiences that will prompt meaningful learning for students. Learning experiences that show the relationship of conceptual elements will create a more effective learning process. Picture books based on visual thinking strategies are very suitable as an alternative to strengthen the design of thematic learning experiences in developing critical thinking for elementary school students. This is affirmed by research results which state that the habit of learning experiences can develop critical thinking skills, one of which is through media development. Furthermore, the development of this media accustoms teachers to be innovative in creating entrepreneurial opportunities as professional educators (Novitasari et al., 2020). According to Katoningsih \& Sutama., (2020), it is necessary to build a training program to improve the entrepreneurship of early childhood educators nowadays.

The overall student response scored 14.1 (maximum score 15) or 'very suitable' category. This student response is related to items; 1 ) the book contents are easy to understand, 2) the content of the story is per the title of the book, 3) the pictures presented are easy to understand, 4) the materials are is following the thematic book, 5) the pictures can be observed clearly, 6) words/sentences in picture books ease students to understand the materials, 7) material in picture books can be read clearly, 8) students can take meanings from pictures presented in picture books, 9) instructions are clear, 10) there is a summary contained in this picture book, 11) students are fond of with picture book, 12) students are interested in this picture book, 13) students are interested in the pictures on every page in this book, 14) this book facilitates students to learn, and 15) students can use this book at home. Based on the total average score, it shows that students strongly agreed with the picture book. Although 
there are suggestions from students and parents stating that the numbers of practice questions must be sorted (there were reversed numbers of questions number 3 and 2). The suggestions from students and parents show that students and parents actively participate in critical thinking. This is supported by the results of research explaining that the ability to think critically at a high level is needed for future demands (Longo, Anderson, \& Wicht, 2020).

Picture books based on visual thinking strategies developed as a whole can be considered as suitable for offline and online thematic learning use. In other words, the developed media can be used as an alternative solution to the online learning process during and postpandemic. This is supported by research results stating that the application of learning using image media can increase students' motivation in thematic learning in elementary schools (Ratnaningsih \& Nastiti, 2018). Likewise, the conclusions of the study that visual learning is very suitable to be used as a learning tool in elementary schools (Alicia, et.al., 2016; Sáez-López, Román-González, \& Vázquez-Cano, 2016)

\section{CONCLUSION}

The book media developed is picture books based on strategic visual thinking, which contains learning materials Theme 7 Sub Theme 3 Learning 5 for third-grade Elementary School students. The books were developed by using the modification of the Borg \& Gall model consisted of 1) needs analysis (library studies, field surveys, and product drafting), 2) development (limited trials and broader trials), and 3) empirical product testing. In term of the feasibility of the developed picture books, media validation experts categorized the media as suitable and facilitated understanding. Presentation of teaching materials with visual thinking strategies based can assist students' understanding of teaching materials and they can imitate the attitudes and skills of the characters presented in picture books. The teachers' responses during learning by utilizing the media gave 'very suitable' category and attracted students' interest in reading. The media attracted students to understand concepts and related them to other concepts that have been mastered. Students' responses during learning by utilizing the developed media gave 'very suitable' category and actively participated in critical thinking. Highlevel critical thinking skills are needed at all levels of learning at school and in the community.

\section{ACKNOWLEDGEMENT}

Researchers would like to thank various parties who have supported this research. We would like to thank the Directorate of Research and Community Service, the Directorate General of Research and Development of the Ministry of Research, Technology, and Higher Education who have facilitated in funding this research. Also, we would like to thank the Director of the Postgraduate School and the Chairman of the UMS Research Institute and staff who have provided facilities and encouragement so that we can complete this research. We would also like to thank the head of the Education Agency, the principal and teachers of SD Muhammadiyah 16 Karangasem, Surakarta, Central Java, who have helped the research activities.

\section{REFERENCES}

Akbar, S., Utari, U., Utami, U., Suwandayani, B. I., Isbadrianingtyas, N., \& Khofiatun. 
DOI: https://doi.org/10.24127/ajpm.v9i4.3165

(2020). Device Development and Implementation of Thematic Learning Process to Improve Quality and Results of Learning in Primary School. 1st International Conference On Information Technology And Education (ICITE 2020) Device, 508(ICITE 2020), 683-690. Atlantis Press.

Buchory, Selly R, S. W. (2017). The Development of A Learning Media for Visualizing the Pancasila Values Based on Information and Communication Technology. Cakrawala Pendidikan: Jurnal Ilmiah Pendidikan, 36(3), 502-521. https://doi.org/https://doi.org/10.21 831/cp.v36i3.12748

Dhull, P., \& Beniwal, R. (2019). Blending Learning: Effective Use of Technology in Classrooms. International Journal of Science and Research (IJSR), 9(7), 15931595. Retrieved from https://www.ijsr.net/get_abstract.p hp?paper_id=ART20199890

Faizah, U. (2009). Keefektifan Cerita Bergambar Untuk Pendidikan Nilai Dan Keterampilan Berbahasa Dalam Pembelajaran Bahasa Indonesia Umi. Cakrawala Pendidikan: Jurnal Ilmiah Pendidikan, 28(3), 249-256. https://doi.org/https://doi.org/10.21 831/cp.v3i3.302

Fatimah, M., Sutama, \& Aly, A. (2020). Religious Culture Development in Community School: a Case Study of Boyolali Middle School, Central Java, Indonesia. Humanities \& Social Sciences Reviews, 8(2), 381388.

https://doi.org/https://doi.org/10.18 510/hssr.2020.8243

Ferrara, V., De Santis, S., \& Staffoli, C. (2015). Art and medicine: From anatomic studies to Visual
Thinking Strategies. Senses and Sciences, 2(2), 40-44. https://doi.org/10.14616/sands2015-

Hailey, D., Miller, A., \& Yenawine, P. (2015). Understanding Visual Literacy: The Visual Thinking Strategies Approach. In Essentials of Teaching and Integrating Visual and Media Literacy: Visualizing Learning (pp. 1-292). https://doi.org/10.1007/978-3-31905837-5

Ishartono, N., Juniati, D., Lukito, A., \& Surabaya, U. N. (2016). Developing Mathematics Teaching Devices in the Topic of Trigonometry Based on Guided Discovery Teaching Method Universitas Muhammadiyah Surakarta 2) 3). Journal of Research and Advances in Mathematics Education, 1(2), 154171. Retrieved from http://journals.ums.ac.id/index.php/ jramathedu

Jayanti, C. D. (2020). Efforts to Improve Thematic Learning Results through Problem Based Learning Model With Power Point Media For Class 2nd Students. Social, Humanities, and Education Studies (SHEs): Conference Series, 3(3), 1311 1314. https://doi.org/https://doi.org/10.20 961/shes.v3i3.46663

Katoningsih, S., \& Sutama. (2020). Needs Analysis of Potential for Early Childhood Educators as Agents of Teacherpreneurship in Karanganyar. International Journal of Innovation, Creativity and Change, 12(6), 123-134.

Kusminah. (2012). The birth of the journal of educational research. Journal of Educational Research, $38(5)$,

321-325. 
DOI: https://doi.org/10.24127/ajpm.v9i4.3165

https://doi.org/https://doi.org/10.10 80/00220671.1945.10881349

Landorf, H. (2006). What's Going on in This Picture? Visual Thinking Strategies and Adult Learning. New Horizons in Adult Education and Human Resource Development, 20(4), 28-32. https://doi.org/https://doi.org/10.10 02/nha3.10267

Latifah, \& Isnalini. (2015). Pengaruh Media Gambar Visual Terhadap Hasil Belajar Siswa Pada Mata Pelajaran Bahasa Inggris di MI AnNur Pekalipan Kota Cirebon. Jurnal Pendidikan Guru MI, 2(1), 1-15. Retrieved from http://id.portalgaruda.org/?ref=bro wse $\&$ mod $=$ viewarticle $\&$ article $=44$ 6934

Longo, P. J., Anderson, O. R., \& Wicht, P. (2020). Visual Thinking Networking Promotes Problem Solving Achievement for 9th Grade Earth Science Students. Electronic Journal of Science Education, 7(1), $1-51$.

Mella Hanifah, D. P., Mudjiran, \& Taufina. (2019). Development of Understanding Reading Teaching Material as an Efforts to Improve Integrated Themat Learning Using the Big Question Strategy in Class $\mathrm{V}$ SD. International Journal of Science and Research (IJSR), 8(1), 1567-1570.

Moeller, B. M., Cutler, K., Fiedler, D., \& Weier, L. (2013). Visual thinking strategies $=$ creative and critical thinking. Phi Delta Kappan, 95(3), 56-60.

https://doi.org/https://doi.org/10.11 77/003172171309500312

Novitasari, M., Sutama, Narimo, S., Fathoni, A., Rahmawati, L., \& Widyasari, C. (2020). Habituation of digital literacy and critical thinking in mathematics in elementary school. International Journal of Scientific and Technology Research, 9(3), 33953399.

Nugrahani, R., \& Rupa, J. S. (2007). Media Pembelajaran Berbasis Visual Berbentuk Permainan Ular Tangga Untuk Meningkatkan Kualitas Belajar Mengajar Di Sekolah Dasar. Lembaran Ilmu Kependidikan, 36(1), 35-44.

Poirier, T. I., Newman, K., \& Ronald, K. (2020). An exploratory study using visual thinking strategies to improve undergraduate students' observational skills. American Journal of Pharmaceutical Education, 84(4), 451-458. https://doi.org/10.5688/ajpe7600

Pritandhari, M. (2002). Penerapan Komik Strip Sebagai Media Pembelajaran Mata Kuliah Manajemen Keuangan Mahasiswa Universitas Muhammadiyah Metro. Jurnal Pendidikan Ekonomi, 4(2), $1-7$.

https://doi.org/https://doi.org/10.24 127/ja.v4i2.631

Rabiman, R., Nurtanto, M., \& Kholifah, N. (2020). Design and development E-learning system by learning management system (LMS) in vocational education. International Journal of Scientific and Technology Research, 9(1), 10591063.

Ratnaningsih, S., \& Nastiti, G. (2018). Upaya Meningkatan Motivasi Belajar Siswa dengan Menggunakan Media Gambar Pada Pembelajaran Tematik di Sekolah Dasar. Al Ibtida: Jurnal Pendidikan Guru MI, 5(2), 275-280. https://doi.org/https://doi.org/10.24 235/al.ibtida.snj.v5i2.3397 
DOI: https://doi.org/10.24127/ajpm.v9i4.3165

Riadi, M. (2020). Pembelajaran Tematik (Pengertian, Karakteristik, Ciri, Jenis dan Langkah-langkahnya). Retrieved December 30, 2020, from Kajian Pustaka website: https://www.kajianpustaka.com/20 20/06/pembelajaran-tematik.html

Rumanti. (2020). Efforts to Increase The Activity Students through Example Non Example Models In Thematic Learning in SD N 1 Karangmalang. Social, Humanities, and Education Studies (SHEs): Conference Series, 3(3), 1422- 1426.

Septyanti, E., Kurniaman, O., \& Charlina. (2020). Development of interactive media based on adobe flash in listening learning for university student. International Journal of Scientific and Technology Research, 9(1), 74-77.

Sutama. (2019). Metode Penelitian Pendidikan; Kuantitatif, Kualitatif, PTK, Mix Methods, $R \& D$. Sukoharjo: CV Jasmine. van den Heuvel-Panhuizen, M., van de Boogaard, S., \& Doig, B. (2009). Picture books stimulate the learning of mathematics. Australian Journal of Early Childhood, 34(3), 30-39. https://doi.org/10.1177/183693910 903400305

Yenawine, P. (2013). Visual Thinking Strategies. Cambridge: Harvard Education Press.

Zhanda, E., Molokwane, T., \& Motshegwa, B. (2020). Integrating Social Media in Teaching and Learning in Higher Education: A Quest for Collaborative Learning in Botswana. International Journal of Scietific and Research (IJSR), 9(4), 131-138. https://doi.org/https://doi.org/10.21 275/SR20402014354 